\title{
Responses of wild fishes to alarm chemicals in pristine and metal-contaminated lakes
}

\author{
Taryn D. McPherson, Reehan S. Mirza, and Greg G. Pyle
}

\begin{abstract}
Responses of wild fish populations to alarm chemicals were examined in clean and metal-contaminated lakes in northern Ontario. Approximately 20 groups of three minnow traps were placed randomly in the littoral zone of each study lake. Within each minnow trap group, one trap was treated with a chemical alarm stimulus (Iowa darter (Etheostoma exile (Girard, 1859)) skin extract, prey-guild species, alarm cue present), one with swordtail (Xiphophorus helleri Heckel, 1848) skin extract (phylogenetically distant and allopatric from darters, alarm cue present but not recognized by darters), and one with distilled water (neutral control). Data included the identification and enumeration of fish captured in each trap after a 10-h set. Darters avoided areas labelled with the alarm stimulus relative to controls only in the clean lake; in contaminated lakes, darters did not avoid areas labelled with the alarm stimulus relative to controls. No effects of contamination on chemosensory function were observed for heterospecific non-darter prey-guild or predator-guild species. These findings suggest that chemical alarm systems do exist in nature, and that these systems appear to be affected by the presence of metals. Such pollution-related effects could lead to increased susceptibility of some fish species to predation and to population declines.
\end{abstract}

Résumé : Nous avons examiné les réactions d'alerte de poissons sauvages dans des lacs propres et des lacs contaminés par les métaux dans le nord de l'Ontario. Nous avons placé au hasard environ 20 groupes de trois nasses à ménés dans la zone littorale de chacun des lacs étudiés. Une des nasses de chaque groupe a été traitée avec un stimulus chimique d'alerte (extrait de peau du dard à ventre jaune (Etheostoma exile (Girard, 1859)), une espèce de la guilde des prédateurs, signal d'alerte présent), la seconde nasse avec de l'extrait de xipho (Xiphophorus helleri Heckel, 1848) (poisson allopatrique et phylogénétiquement éloigné des dards, signal d'alerte présent, mais non reconnu par les dards) et la dernière avec de l'eau distillée (témoin neutre). Les données comprennent l'identification et l'énumération des poissons capturés dans chaque piège au bout de $10 \mathrm{~h}$. Les dards évitent plus les zones marquées par le signal d'alerte que les zones témoins seulement dans le lac témoin. Dans les lacs contaminés, cependant, les dards n'évitent pas les régions marquées avec le signal d'alarme plus que les zones témoins. Nous n'avons observé aucun effet de la contamination sur la fonction chimiosensorielle chez les espèces hétérospécifiques autres que les dards appartenant aux guildes des proies ou des prédateurs. Ces données indiquent que les systèmes d'alerte chimique existent en nature et que ces systèmes semblent être affectés par la présence de métaux. De tels effets reliés à la pollution pourraient entraîner une vulnérabilité accrue de certaines espèces de poissons à la prédation et au déclin de certaines populations.

[Traduit par la Rédaction]

\section{Introduction}

Predation is a strong selection pressure for the production of antipredator behaviours and adaptations (Lima and Dill 1990), whether morphological, physiological, life historical, or behavioural (Kats and Dill 1998). Therefore, the ability to continuously monitor predation risk is vital. The transmission of chemical information influences predator-prey interactions in aquatic environments, providing prey-guild fishes with information about predation risk. Within Ostariophysan fishes (minnows, characins, and catfishes), alarm cues are

Received 26 August 2003. Accepted 2 March 2004. Published on the NRC Research Press Web site at http://cjz.nrc.ca on 22 June 2004.

T.D. McPherson and G.G. Pyle. ${ }^{\mathbf{1}}$ Department of Biology, Nipissing University, P.O. Box 5002, 100 College Drive, North Bay, ON P1B 8L7, Canada.

R.S. Mirza. Department of Biology, Concordia University, 7141 Sherbrooke W., Montreal, QC H4B 1R6, Canada.

${ }^{1}$ Corresponding author (e-mail: gregp@ nipissingu.ca). localized in specialized epidermal club cells (Smith 1979; Brown and Smith 1997; Commens and Mathis 1999). Darters have analogous epidermal cells called sacciform cells, but it is not known whether these cells contain alarm cues. Alarm cues are released to the water only upon mechanical damage to the skin, as during a predatory attack (Smith 1979, 1992; Brown and Godin 1999; Commens and Mathis 1999). These chemical alarm cues are thought to be perceived by the olfactory system in several taxonomically diverse fish species, including Ostariophysans, sticklebacks, poeciliids, percids (including darters), gobies, sculpins, salmonids, and cichlids (Smith 1992; Chivers and Smith 1998). In prey-guild fishes, these cues induce antipredator behavioural responses such as increased shoaling, shelter use, freezing, and dashing; reduced foraging; and area avoidance (Brown and Godin 1997, 1999; Chivers and Smith 1998). Although behavioural responses vary among species, they all serve to enhance survival by reducing predation risk through decreased detection and capture (Mathis and Smith 1993) and subsequent increased probability of escape (Mirza and Chivers 2000, 2001; Gazdewich and 
Chivers 2002). On the other hand, chemical alarm cues emitted by prey-guild fishes may attract predatory fishes to the area where the cue was released (Chivers et al. 1996; Brown and Godin 1999).

Chemical alarm signalling is an integral component of many prey species' antipredator arsenal. Receptor cells that are sensitive to alarm cues are located in the olfactory epithelium (Klima and Applehans 1990) and are directly and continuously in contact with the aquatic environment (Julliard et al. 1995). But what happens when this olfactory epithelium is exposed to chemical pollution such as aqueous metals? Laboratory studies have shown that aqueous metal contamination affects freshwater fishes and their ability to perceive chemical signals (Julliard et al. 1995; Scott et al. 2003). Hansen et al. (1999a) reported that chinook salmon (Oncorhynchus tshawytscha (Walbaum in Artedi, 1792)) pre-exposed to $2 \mu \mathrm{g} \mathrm{Cu} / \mathrm{L}$ failed to avoid potentially toxic $\mathrm{Cu}$ concentrations $(>44 \mu \mathrm{g} / \mathrm{L})$ owing to $\mathrm{Cu}$-induced damage to olfactory epithelium during the pre-exposure period. This $\mathrm{Cu}$ concentration $(2 \mu \mathrm{g} / \mathrm{L})$, sufficient to impair an avoidance response to subsequent exposures to toxic $\mathrm{Cu}$ concentrations, is at the low end of the range $(2-4 \mu \mathrm{g} / \mathrm{L})$ recommended in the Canadian Water Quality Guidelines for the Protection of Aquatic Life (Canadian Council of Ministers of the Environment 1999) and is several times lower than concentrations typically measured in contaminated lakes near metal mining operations (e.g., 4-22 $\mu \mathrm{g} / \mathrm{L}$; Couture and Rajotte 2003).

Other studies have reported that olfactory impairment may be only a transient effect of damage to olfactory epithelium. Beyers and Farmer (2001) reported that olfactory function recovered in Colorado pikeminnows (Ptychocheilus lucius Girard, 1856) despite continuous exposure to $66 \mu \mathrm{g} \mathrm{Cu} / \mathrm{L}$ for up to $96 \mathrm{~h}$. Physical severance of the olfactory nerve also results in initial loss of olfactory function followed by regeneration and functional recovery (Evans and Hara 1985). However, the question of whether or not wild fish can adapt to persistently elevated metal concentrations in their environment and respond to important chemical cues, such as alarm substance, remains unexplored.

The main objective of this study was to determine whether chronic metal exposure affects the ability of wild fish to perceive chemical cues in their environment. Our hypothesis was that chemical alarm cues derived from skin extract of an indigenous prey-guild fish will not induce antipredator behavioural responses among sympatric prey-guild fish species when tests are performed in metal-contaminated lakes owing to impairment of olfactory function by the metal contamination. If fish in metal-polluted lakes do not respond to alarm cues and fish from reference (i.e., uncontaminated) lakes do respond, then it is possible that environmental metal contamination leads to an impairment of alarm cue reception in these fish. The long-term ecological effects of industrial metal pollution on chemical cue perception in wild preyguild fishes could lead to significant "bottom-up" ecological perturbations because prey-guild species may not be able to adequately assess predation risk; these perturbations could lead to population declines. On the other hand, if fishes from metal-contaminated sites still demonstrate a fright response to alarm cues, physiological adaptation mechanisms may be reducing the influence of metals on this communication system.

\section{Materials and methods}

\section{Test fish}

Iowa darters (Etheostoma exile (Girard, 1859)) were used as a source of prey-guild alarm substance. They were collected in July 2002 (post spawn) from James Lake, on the Nipissing University - Alcan Environmental Research Preserve, in northern Ontario, Canada. This is an unpolluted, remote lake that has no public access, receives no direct anthropogenic inputs, and served as a reference site during this study. Iowa darters were collected in July because some fishes have been shown to cease production of alarm substance during spawning season (Smith 1976, 1992), which, for Iowa darters, occurs in the latter part of May and early June (Breder and Rosen 1966). Darters are small, cryptic, bottom-dwelling fish that typically respond to Iowa darter alarm substance with a reduction or cessation of movement (Smith 1992; Commens and Mathis 1999). Iowa darters were chosen for this study because they are known to occur in all the study lakes and because details about their chemical communication system are known (Smith 1979).

\section{Test sites}

Experiments were conducted in lakes that ranged in their degree of metal contamination: James (pristine), Ramsey (intermediate), and Kelly (contaminated) (Fig. 1; Table 1). Metals of concern in Sudbury-area lakes include copper, nickel, and, to a lesser extent, zinc. James Lake $\left(46^{\circ} 17^{\prime} 21^{\prime \prime} \mathrm{N}\right.$, $\left.78^{\circ} 59^{\prime} 26^{\prime \prime} \mathrm{W}\right)$ served as a reference site, whereas Ramsey and Kelly lakes, both located in Sudbury, Ontario, served as contaminated sites. Ramsey Lake $\left(46^{\circ} 28^{\prime} 39^{\prime \prime} \mathrm{N}, 80^{\circ} 56^{\prime} 45^{\prime \prime} \mathrm{W}\right)$ receives atmospheric deposition of acid and metals from nickel and copper smelting operations in the vicinity. This urban lake is also subject to the influence of road salts, metals, and pesticides from urban stream runoff and to combustion by-products from recreational vehicle traffic on the lake. Kelly Lake $\left(46^{\circ} 26^{\prime} 55^{\prime \prime} \mathrm{N}, 81^{\circ} 03^{\prime} 57^{\prime \prime} \mathrm{W}\right)$, which lies downstream of the city and mining operations, is the "storehouse of contamination". All waterborne pollution flowing southwest passes through Kelly Lake. Municipal sewage effluents further contaminate the lake through phosphorus loading.

\section{Experimental design}

Field experimentation was conducted to determine whether prey-guild fish species inhabiting metal-contaminated lakes avoid areas labelled with Iowa darter skin extract (chemical alarm stimulus), relative to their responses in a reference lake (i.e., pristine and uncontaminated by metals). To test behavioural responses - specifically, area avoidance minnow traps were placed in suspected fish habitat and each trap in a set of three was individually treated with one of three stimuli: (1) Iowa darter skin extract (chemical alarm stimulus), (2) swordtail (Xiphophorus helleri Heckel, 1848) skin extract (fish control), and (3) distilled water (neutral control) (Lima and Dill 1990; Chivers and Smith 1998). Swordtails are distantly related to darters; hence, darters do not respond to injured swordtails with an antipredator re- 
Fig. 1. Map showing locations where experiments were conducted in North Bay (James Lake) and Sudbury (Ramsey and Kelly lakes), northern Ontario, Canada during the summer of 2002.

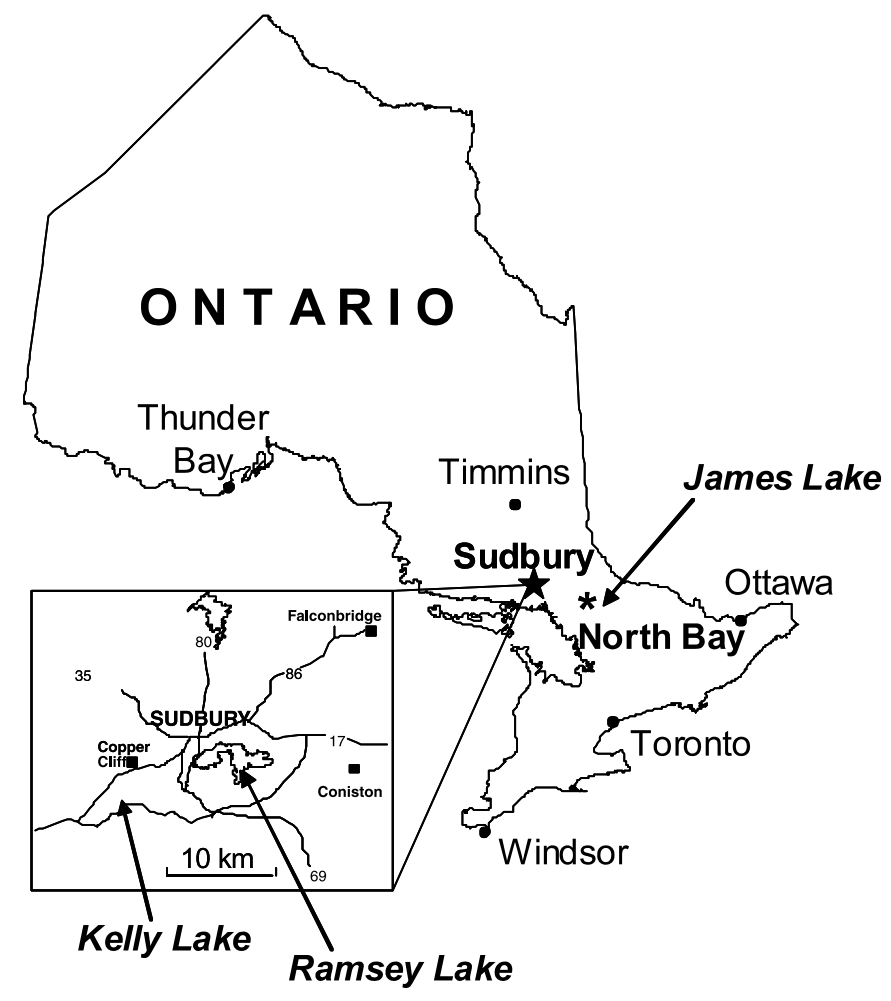

sponse. However, injured fish skin includes amino acids that may cause swordtail skin to be somewhat attractive to darters.

Stainless steel wire was used to suspend a $1-\mathrm{cm}^{3}$ synthetic foam sponge in the centre of each minnow trap. The sponge was saturated with $1 \mathrm{~mL}$ of one of the three stimuli. Each trap was baited with five dog food kibbles to enhance attraction to traps (Chivers and Smith 1998; Brown and Godin 1999). Traps were placed in the littoral zone of each lake, with traps within individual trials being placed according to a randomized block design. Individual traps were separated by at least $10 \mathrm{~m}$ so that the chemical stimulus from one trap would not influence the behavioural response to the chemical stimulus of another trap (Brown and Godin 1999). Since fish, especially those that are not in direct contact with predators, may have delayed responses to stimuli (Smith 1992), experimental trials lasted approximately $10 \mathrm{~h}$.

Fish that entered traps were identified, enumerated, and released. Captured fish were coded to guild: prey (brook stickleback, Culaea inconstans (Kirtland, 1841); fathead minnow, Pimephales promelas Rafinesque, 1820; golden shiner, Notemigonus crysoleucas (Mitchill, 1814); Iowa darter; johnny darter, Etheostoma nigrum Rafinesque, 1820; threespine stickleback, Gasterosteus aculeatus L., 1758; white sucker, Catostomus commersoni (Lacépède, 1803)) and predator (brown bullhead, Ameiurus nebulosus (Lesueur, 1819); pumpkinseed sunfish, Lepomis gibbosus (L., 1758); rock bass, Ambloplites rupestris (Rafinesque, 1817); smallmouth bass, Micropterus dolomieu Lacépède, 1802; yellow perch, Perca flavescens (Mitchill, 1814)).

\section{Experimental stimulus preparation}

We followed the skin extract preparation methods utilized by Brown and Godin (1997). Chemical stimuli (skin extracts) were generated by taking skin samples from donor Iowa darters and swordtails. Donor fish were sacrificed with a single blow to the head, as outlined in guidelines set by the Canadian Council on Animal Care (Olfert et al. 1993). Skin was removed, homogenized, filtered to remove remaining tissue or scales, and diluted with distilled water. Final stimulus concentrations were $2.5 \mathrm{~g}$ skin/L distilled water. Distilled water was treated in the same manner as the other stimuli (except for the addition of homogenized fish skin) and was used as a neutral control.

\section{Statistical analysis}

Statistical analysis included data where at least one trap in each block of three caught at least one fish. Trials that failed to capture a fish in any treatment were removed from subsequent analysis. Because we expected that fish would avoid traps treated with alarm cue (Chivers and Smith 1998), data were analysed by one-tailed contingency analysis. Traps treated with alarm cue were assigned to one of two categories: (1) those that caught greater or equal numbers of fish compared with the controls, or (2) those that caught fewer fish than the controls. Separate analyses were conducted to compare alarm cue responses with responses to each of the two controls. Consequently, $\alpha$ was adjusted using a modified Bonferroni adjustment to manage experiment-wise error rate, which resulted in a significance level of 0.05 (Keppel 1982). Therefore, the contingency analysis included a comparison of the proportion of traps falling under each of the two trap categories between reference and metal-contaminated lakes. This analysis was conducted for Iowa darters, all darter species (i.e., total darters), prey-guild species, and predator-guild species.

\section{Results}

\section{Fish diversity}

Prey- and predator-guild diversity was variable among pristine and contaminated lakes (Table 2). James Lake (reference site) had the greatest variety of both prey- and predator-guild fish species, including members of the families Percidae (prey- and predator-guild) and Centrarchidae (predator-guild). Ramsey Lake (intermediate) was dominated by a range of predator-guild fish species (Centrarchidae, Ictaluridiae, Percidae) and there was no representation of prey-guild fish species during the sampling period. Kelly Lake (most contaminated) was dominated by a wide variety of prey-guild fish species (Catostomidae, Cyprinidae, Gasterosteidae, Percidae) and there was minimal representation of predator-guild fish species (Percidae). Interestingly, the greatest number of fish species was found in the most contaminated lake (eight species, Kelly Lake), followed by the intermediate lake (seven species, Ramsey Lake), while the lowest number of species was found in the reference lake 
Table 1. Degree of contamination, as indicated by $\mathrm{pH}$ and total metal concentrations in water and sediments, of lakes in which experiments were conducted.

\begin{tabular}{|c|c|c|c|c|c|c|c|c|}
\hline \multirow[b]{2}{*}{ Lake } & \multirow[b]{2}{*}{$\mathrm{pH}^{a}$} & \multicolumn{4}{|c|}{ Metal concentrations in water $(\mu \mathrm{g} / \mathrm{L})$} & \multicolumn{3}{|c|}{$\begin{array}{l}\text { Metal concentrations in } \\
\text { sediment }(\mu \mathrm{g} / \mathrm{kg})\end{array}$} \\
\hline & & $\mathrm{Ca}$ & $\mathrm{Cu}$ & $\mathrm{Ni}$ & $\mathrm{Zn}$ & $\mathrm{Cu}$ & $\mathrm{Ni}$ & $\mathrm{Zn}$ \\
\hline \multicolumn{9}{|l|}{ James } \\
\hline Mean & 8.0 & 15169 & 1.2 & 0.9 & 11.6 & 30 & 19 & 1.7 \\
\hline $\mathrm{SEM}^{b}$ & $(7.9-8.3)$ & 1406 & 0.3 & 0.1 & 8.6 & 2 & 1 & 0.1 \\
\hline \multicolumn{9}{|l|}{ Ramsey } \\
\hline Mean & 8.0 & 14003 & 9.7 & 52 & 5.7 & 1606 & 1890 & 181 \\
\hline SEM & $(7.9-8.0)$ & 1030 & 0.3 & 2.6 & 0.7 & 495 & 1053 & 83 \\
\hline \multicolumn{9}{|l|}{ Kelly } \\
\hline Mean & 8.4 & 204437 & 15 & 338.2 & 11.7 & 2672 & 4678 & 394 \\
\hline SEM & $(8.4-8.4)$ & 5175 & 1.5 & 34.7 & 3.3 & 1059 & 1787 & 150 \\
\hline
\end{tabular}

Note: Water and sediment samples $(n=3)$ were collected from each lake (G.G. Pyle, J.W. Rajotte, and $\mathrm{P}$. Couture, unpublished data).

${ }^{a}$ The median $\mathrm{pH}$ is given and the range is indicated in parentheses.

${ }^{b} \mathrm{SEM}$, standard error of the mean (values reported for $\mathrm{pH}$ represent the $\mathrm{pH}$ range).

Table 2. Prey and predator capture results for pristine (James Lake) and contaminated lakes (Ramsey and Kelly lakes) used in field experiments during the summer of 2002.

\begin{tabular}{lllll}
\hline \multirow{2}{*}{ Guild } & Species & $\begin{array}{l}\text { James } \\
\text { Lake }\end{array}$ & $\begin{array}{l}\text { Ramsey } \\
\text { Lake }\end{array}$ & $\begin{array}{l}\text { Kelly } \\
\text { Lake }\end{array}$ \\
\hline Prey & brook stickleback, Culaea inconstans & & & + \\
& fathead minnow, Pimephales promelas & & & + \\
& golden shiner, Notemigonus crysoleucas & & & + \\
& Iowa darter, Etheostoma exile & + & $+*$ & + \\
& johnny darter, Etheostoma nigrum & + & $+*$ & + \\
& threespine stickleback, Gasterosteus aculeatus & & & + \\
& white sucker, Catostomus commersoni & & & \\
Predator & brown bullhead, Ameiurus nebulosus & & + & \\
& pumpkinseed sunfish, Lepomis gibbosus & + & + & \\
& rock bass, Ambloplites rupestris & + & + & \\
& smallmouth bass, Micropterus dolomieu & & + & + \\
& yellow perch, Perca flavescens & + & + & \\
\hline
\end{tabular}

Note: A plus sign (+) indicates species presence within a lake.

*Captured only during preliminary sampling.

(five species, James Lake). The only species captured in all of the lakes during the sampling period was yellow perch.

\section{Area avoidance}

No darters or prey-guild fish species were captured in Ramsey Lake during the experiment. Consequently, Ramsey Lake was removed from the darter and prey-guild response analyses (Table 2). Iowa darters avoided traps treated with alarm cue relative to those treated with distilled water more effectively in James Lake (reference) than in Kelly Lake (contaminated) $\left(\chi^{2}=3.86, P=0.02\right.$; Fig. $\left.2 a\right)$. In Kelly Lake, all of the traps treated with alarm cue caught more Iowa darters than traps treated with distilled water. Similarly, a proportionately greater number of traps treated with swordtail skin extract caught more Iowa darters than traps treated with alarm cue in James Lake relative to Kelly Lake $\left(\chi^{2}=3.29, P=0.03\right.$; Fig. $\left.2 c\right)$. A similar pattern of response was observed when all darter species were considered together. Fewer traps treated with alarm cue captured more darters than traps treated with distilled water in James Lake relative to Kelly Lake $\left(\chi^{2}=5.18, P=0.01\right.$; Fig. $\left.2 b\right)$. However, there was no statistical difference between James and Kelly lakes with respect to total darter alarm cue avoidance relative to the response to swordtail skin extract $\left(\chi^{2}=1.24\right.$, $P=0.13$; Fig. $2 d$ ).

Prey-guild fish did not appear to respond to the Iowa darter alarm cue. Although $67 \%$ of the traps treated with alarm cue caught fewer fish than traps treated with distilled water in James Lake, compared with $50 \%$ in Kelly Lake, the response was not statistically significant $\left(\chi^{2}=0.59, P=\right.$ 0.22). Similarly, $70 \%$ of the traps treated with alarm cue caught fewer prey-guild fish relative to traps treated with swordtail skin extract in James Lake, compared with $45 \%$ in Kelly Lake. However, this effect was also not significant $\left(\chi^{2}=1.31, P=0.13\right)$.

Predator-guild fish were caught in all three study lakes, so all three lakes were included in the analysis of predatorguild fish response to Iowa darter alarm cue. In all cases, predator-guild fish did not seem to respond to the alarm cue. Although $100 \%$ of traps in Kelly Lake that were treated with 
Fig. 2. Wild darter response to Iowa darter (Etheostoma exile) alarm cues in a clean (James Lake) and a metal-contaminated lake (Kelly Lake). Black bars represent the proportion of traps treated with Iowa darter alarm cue that caught greater or equal numbers of fish than traps treated with either distilled water $(a, b)$ or swordtail (Xiphophorus helleri) skin extract $(c, d)$ controls. White bars indicate the proportion of traps treated with Iowa darter alarm cue that caught fewer fish than either of the controls. Panels on the left represent the response of Iowa darters, whereas panels on the right represent the response of all darter species together. Data were analysed by contingency analysis. Responses in panels $a, b$, and $c$ were significant $(P<0.05)$.

\section{lowa darters Total darters}

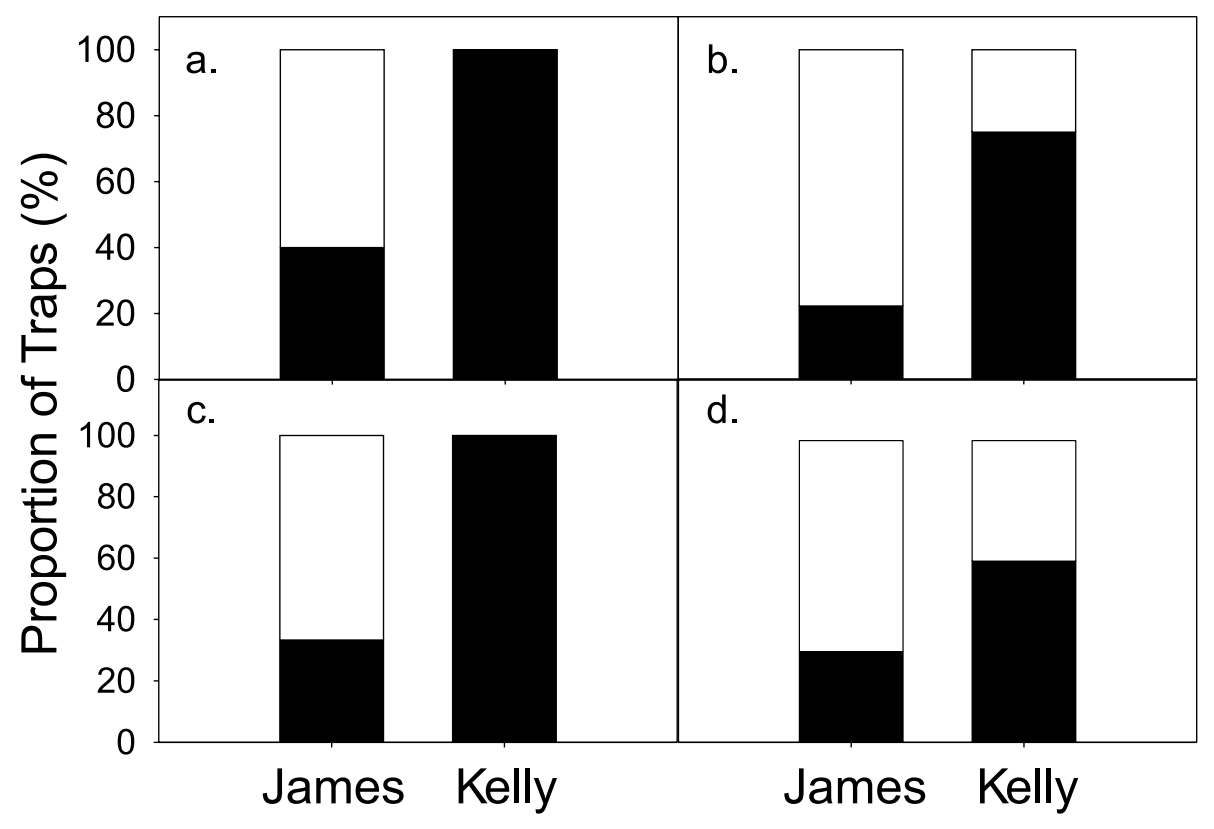

alarm cue caught more predatory fish relative to traps treated with distilled water, compared with $57 \%$ and $50 \%$ in James and Ramsey lakes, respectively, the effect was not significant $\left(\chi^{2}=3.51, P=0.09\right)$. Similarly, $75 \%$ of Kelly Lake traps treated with alarm cue caught more predatory fish relative to traps treated with swordtail skin extract, compared with $50 \%$ in both James and Ramsey lakes. Again, the effect was not significant $\left(\chi^{2}=0.90, P=0.32\right)$.

\section{Discussion}

Our study is the first to demonstrate that wild fishes inhabiting metal-contaminated environments exhibit an impaired response to chemical alarm stimulus under natural conditions. This was evident because darters avoided areas labelled with Iowa darter alarm stimulus in a reference lake but not in a metal-contaminated lake. It is suspected that free metal cations present in metal-contaminated lakes disrupt olfaction by damaging olfactory epithelium, leading to an impairment of olfactory function (Klima and Applehans 1990; Hansen et al. 1999b; Beyers and Farmer 2001; Scott et al. 2003). However, some research suggests that fish exposed to elevated concentrations of aqueous metals can maintain chemosensory function in the long term through physiological adaptation and the development of tolerance with increasing exposure time (Hara 1994; Julliard et al. 1995; Beyers and Farmer 2001). Beyers and Farmer (2001) reported that an initial loss of olfactory ability occurred during the first $24 \mathrm{~h}$ of exposure to a range of copper concentrations ( $<10$ to $266 \mu \mathrm{g} / \mathrm{L}$ ), but within days, olfactory ability recovered in fish held at concentrations $<66 \mu \mathrm{g} / \mathrm{L}$ owing to the induction of protective mechanisms such as increased mucus production, the induction of detoxifying mechanisms, or metal sequestration by melanophores. Experimental severance of rainbow trout olfactory nerves (Evans and Hara $1985)$ or treatment of the olfactory organ with toxicants (Evans et al. 1982) caused degeneration of the olfactory neurons, followed by their replacement with new functional neurons. In addition, Julliard et al. (1995) reported that fish acclimated for $60 \mathrm{~d}$ to chronic low-level copper exposure demonstrated cytomorphological recovery in the olfactory epithelium. They suggested that copper sequestration by melanophores contributed to increased fish chemosensory tolerance to metals.

The results of this study do not support these previous findings of adaptation and recovery of chemosensory function after chronic metal exposure in wild fish. Instead, wild darters inhabiting metal-contaminated lakes demonstrated chemical communication impairment that could potentially lead to increased susceptibility to predation and possibly population declines. There are several possible explanations for the discrepancies between this study and other published results. The latter are typically based on experiments conducted in the laboratory. Although laboratory-based studies provide data that contribute to mechanistic understanding, results are difficult to extrapolate to wild populations because laboratory conditions do not always represent natural conditions. Furthermore, unlike laboratory animals, wild fish are continuously in contact with metals for the duration of their lives and over generations, never experiencing respite 
from metal contamination that may allow for recovery from metal-induced olfactory damage. Also, one of the contaminated lakes in this study (Kelly Lake) receives contamination from many sources (domestic effluent, urban runoff, etc.), and it is possible that some other nonmetal contaminant might contribute to the observed chemosensory inhibition. Results of this study coincide more with those of Cancalon (1982), who reported that regeneration of olfactory cells followed contaminant-induced degeneration, but during the period of regeneration (lasting a few days to several months) fish were unable to locate food. Because olfaction also plays an important role in fish migration, reproduction, and predator recognition and avoidance (Magurran 1989; Julliard et al. 1995), it seems likely that the impairment of the olfactory system may impair not only a fish's ability to locate food, but also its ability to detect and avoid predation.

Commens and Mathis (1999) reported that prey-guild fishes are able to recognize and respond to alarm signals of sympatric heterospecific prey-guild fish. Results reported here indicate that sympatric heterospecific prey-guild fishes inhabiting a non-contaminated lake do not respond to the chemical cue of the Iowa darter. This is probably because Iowa darters are not a preferred prey species, owing to their small size, wide dispersal within an ecosystem, cryptic coloration, and benthic habits. We chose Iowa darters for this study because they were common to all our study lakes. However, had we chosen a preferred prey species, we may have observed chemosensory impairment in the metalcontaminated lake, indicated by the inability of prey-guild species to respond to a heterospecific alarm cue. This conjecture warrants further investigation.

Although our data are limited, we hypothesize that metalinduced impairment of the ability to perceive and respond to alarm cues contributes to the dominance of either prey- or predator-guild fish in metal-contaminated lakes. Capture statistics from James Lake (reference) suggested a sort of predator-prey equilibrium, as indicated by approximately equal numbers of prey-guild and predator-guild species. On the other hand, Ramsey Lake was dominated by predatorguild species, and Kelly Lake was dominated by prey-guild species. Although our data represent only a qualitative snapshot of species present at the time of sampling, metalinduced impairment of chemosensory predator detection systems might contribute to increased amplitude in predator-prey population cycling in metal-contaminated ecosystems. Much more research is required to understand the effects of contaminant impairment of chemosensory function at the ecosystem level.

Darters are known to assess predation risk through chemical communication signals and to respond to these signals with decreased activity and increased "freezing" behavior, which lowers the probability of detection by a predator (Smith 1979; Commens and Mathis 1999; Haney et al. 2001). Because darter behavioural response is less robust (i.e., more affected by hunger, crowding, and disturbance) than the Ostariophysian response (Smith 1979), caution must be used in interpreting apparently negative responses of darters to alarm cues (Chivers and Smith 1998). In previous work, Iowa darters did not show a strong or consistent reduction in activity in response to johnny darter extract (Smith 1979), indicating the lack of a family-wide homology of the chemosensory apparatus for alarm signal reception (Smith 1979; Commens and Mathis 1999).

Although minnow chemical alarm cues have been shown to attract predators (Brown and Godin 1999), the predatory species in this study did not show a significant preference for areas labelled with Iowa darter alarm stimulus. Prey- and predator-guild abundance and diversity may account for this unexpected finding. Predator-guild fishes may be less inclined to respond to alarm cues when other prey fishes are readily available, as was the case in Kelly Lake. Alternatively, it may be inferred that chronic metal contamination has impaired the ability of predator-guild fishes to respond to the alarm cues of a prey-guild fish species. This too might explain why Kelly Lake was dominated by a diverse range of prey-guild fish and only one predatory species. Unfortunately, neither interpretation explains why predatory species showed no significant preference for areas labelled with the alarm stimulus in the pristine environment (James Lake). It is possible, however, since darters are not preferred prey items in these systems, that the lack of attraction of predators to areas labelled with darter alarm cue reflects the fact that predators have not learned to recognize darter alarm cue.

In summary, the impairment of olfactory ability, whether short-term or long-term, can potentially have a high biological cost. Olfaction influences a range of fish behaviours, most notably predator recognition and avoidance. Results of this study suggest that chemical communication among darter species is intact in pristine lakes but impaired in chronically metal-contaminated lakes. Therefore, darters within pristine environments continue to enjoy survival benefits associated with intact chemical communication systems (Mathis and Smith 1993; Mirza and Chivers 2001), but those within contaminated environments do not enjoy such benefits because of impaired chemosensory function. This impairment could potentially hinder predator recognition and avoidance, leading to an increased susceptibility to predation. This effect of metals on a fish's ability to perceive predators may contribute to predator-prey population cycling dynamics, although further research is required to confirm this. Metal-induced chemosensory impairment in fish inhabiting metal-polluted lakes may lead to significant consequences to ecosystem integrity and may represent the first glimpse of a much more general effect of metal contamination that could involve many aquatic species.

\section{Acknowledgements}

Thanks are owed to Dr. Patrice Couture of Laurentian University and Pat Frair and Peter Brown of Canadore College for logistical support. Thanks also to Charles Gauthier, Stephanie Lyons, Kristen McPherson, Billy Solmes, and Jimmy Vincent for their help in the field, and to Kristen McPherson for her help in the laboratory. Scientific collection permits were obtained from the Ontario Ministry of Natural Resources. All procedures adhered to Canadian Council on Animal Care guidelines. Charles Gauthier provided critical comments that improved the manuscript. An internal research grant from Nipissing University to G.G.P. funded this study. 


\section{References}

Beyers, D.W., and Farmer, M.S. 2001. Effects of copper on olfaction of Colorado pikeminnow. Environ. Toxicol. Chem. 20: 907-912.

Breder, C.M., Jr., and Rosen, D.E. 1966. Modes of reproduction in fishes. The Natural History Press, Garden City, N.Y.

Brown, G.E., and Godin, J.-G.J. 1997. Anti-predator responses to conspecific and heterospecific skin extracts by threespine sticklebacks: alarm pheromones revisited. Behaviour, 134: 1123-1134.

Brown, G.E., and Godin, J.-G.J. 1999. Chemical alarm signals in wild Trinidadian guppies (Poecilia reticulata). Can. J. Zool. 77: 562-570.

Brown, G.E., and Smith, R.J.F. 1997. Conspecific skin extracts elicit antipredator responses in juvenile rainbow trout (Oncorhynchus mykiss). Can. J. Zool. 75: 1916-1922.

Canadian Council of Ministers of the Environment. 1999. Canadian water quality guidelines for the protection of aquatic life. In Canadian environmental quality guidelines. Canadian Council of Ministers of the Environment, Winnipeg, Man.

Cancalon, P. 1982. Degeneration and regeneration of olfactory cells induced by $\mathrm{ZnSO}_{4}$ and other chemicals. Tissue Cell, 14: 717-733.

Chivers, D.P., and Smith, R.J.F. 1993. The role of olfaction in chemosensory-based predator recognition in the fathead minnow, Pimephales promelas. J. Chem. Ecol. 19: 623-633.

Chivers, D.P., and Smith, R.J.F. 1998. Chemical alarm signalling in aquatic predator-prey systems: a review and prospectus. Ecoscience, 5: 338-352.

Chivers, D.P., Brown, G.E., and Smith, R.J.F. 1996. The evolution of chemical alarm signals: attracting predators benefits alarm signal senders. Am. Nat. 148: 649-659.

Commens, A.M., and Mathis, A. 1999. Alarm pheromones of rainbow trout darters: responses to skin extracts of conspecifics and congeners. J. Fish Biol. 55: 1359-1362.

Couture, P., and Rajotte, J.W. 2003. Morphometric and metabolic indicators of metal stress in wild yellow perch (Perca flavescens) from Sudbury, Ontario: a review. J. Environ. Monit. 5: 216-221.

Evans, R.E., and Hara, T.J. 1985. The characteristics of the electroolfactogram (EOG): its recovery following olfactory nerve section in rainbow trout. Brain Res. 330: 65-75.

Evans, R.E., Zielinski, B., and Hara, T.J. 1982. Development and regeneration of the olfactory organ in rainbow trout. In Chemoreception in fishes. Edited by T.J. Hara. Elsevier, Amsterdam, Netherlands. pp. 15-37.

Gazdewich, K.J., and Chivers, D.P. 2002. Acquired predator recognition by fathead minnows: influence of habitat characteristics on survival. J. Chem. Ecol. 28: 439-445.

Haney, D.C., Vokoun, J.C., and Noltie, D.B. 2001. Alarm pheromone recognition in a Missouri darter assemblage. J. Fish Biol. 59: 810-817.

Hansen, J.A., Marr, J.C.A., Lipton, J., Cacela, D., and Bergman, H.L. 1999a. Differences in neurobehavioral responses of chi- nook salmon (Oncorhynchus tshawytscha) and rainbow trout (Oncorhynchus mykiss) exposed to copper and cobalt: behavioral avoidance. Environ. Toxicol. Chem. 18: 1972-1978.

Hansen, J.A., Rose, J.D., Jenkins, R.A., Gerow, K.G., and Bergman, H.L. 1999b. Chinook salmon (Oncorhynchus tshawytscha) and rainbow trout (Oncorhynchus mykiss) exposed to copper: neurophysiological and histological effects on the olfactory system. Environ. Toxicol. Chem. 18: 1979-1991.

Hara, T.J. 1994. Olfaction and gustation in fish: an overview. Acta Physiol. Scand. 152: 207-217.

Julliard, A.K., Saucier, D., and Astic, L. 1995. Metal X-ray microanalysis in the olfactory system of rainbow trout exposed to low level of copper. Biol. Cell (Paris), 83: 77-86.

Kats, L.B., and Dill, L.M. 1998. The scent of death: chemosensory assessment of predation risk by prey animals. Ecoscience, 5: 361-394.

Keppel, G. 1982. Design and analysis: a researcher's handbook. Prentice-Hall Inc., Englewood Cliffs, N.J.

Klima, K.E., and Applehans, F.M. 1990. Copper exposure and the degeneration of olfactory receptors in rainbow trout (Oncorhynchus mykiss). Chem. Speciat. Bioavailab. 2: 149-154.

Lima, S.L., and Dill, L.M. 1990. Behavioral decisions made under the risk of predation: a review and prospectus. Can. J. Zool. 68: 619-640.

Magurran, A.E. 1989. Acquired recognition of predator odour in the European minnow (Phoxinus phoxinus). Ethology, 82: 216223.

Mathis, A., and Smith, R.J.F. 1993. Chemical alarm signals increase the survival time of fathead minnows (Pimephales promelas) during encounters with northern pike (Esox lucius). Behav. Ecol. 4: 260-265.

Mirza, R.S., and Chivers, D.P. 2000. Predator recognition-training enhances survival of brook trout: evidence from laboratory and field studies. Can. J. Zool. 78: 2198-2208.

Mirza, R.S., and Chivers, D.P. 2001. Chemical alarm signals enhance survival of brook charr (Salvelinus fontinalis) during encounters with chain pickerel (Esox niger). Ethology, 107: 9891005 .

Olfert, E.D., Cross, B.M., and McWilliam, A.A. (Editors). 1993. Guide to the care and use of experimental animals. Vol. 1. 2nd ed. Canadian Council on Animal Care, Ottawa, Ont.

Scott, G.R., Sloman, K.A., Rouleau, C., and Wood, C.M. 2003. Cadmium disrupts behavioural and physiological responses to alarm substance in juvenile rainbow trout (Oncorhynchus mykiss). J. Exp. Biol. 206: 1779-1790.

Smith, R.J.F. 1976. Seasonal loss of alarm substance cells in North American cyprinoid fishes and its relation to abrasive spawning behavior. Can. J. Zool. 54: 1172-1182.

Smith, R.J.F. 1979. Alarm reaction of Iowa and johnny darters (Etheostoma, Percidae, Pisces) to chemicals from injured conspecifics. Can. J. Zool. 57: 1278-1282.

Smith, R.J.F. 1992. Alarm signals in fishes. Rev. Fish Biol. Fish. 2: 33-63. 